\title{
Will the Information Disclosure Quality Reduce the Executives' Excess Perks? - Evidence from China
}

\author{
$\operatorname{Han} \mathrm{Li}^{1}$ \\ ${ }^{1}$ SILC Business School, Shanghai University, Shanghai, China \\ Correspondence: Han Li, SILC Business School, Shanghai University, 20 Chengzhong Road, JiaDing District, \\ Shanghai 201800, China. Tel: 86-21-6998-0028 ext.53101.
}

Received: January 26, 2016

Accepted: February 17, 2016

Online Published: March 8, 2016

doi:10.5430/ijfr.v7n2p73

URL: http://dx.doi.org/10.5430/ijfr.v7n2p73

\begin{abstract}
Perquisites (abbreviated as Perks) spent by managers, especially by top executives reflect the agency problems in essence. This paper investigates the relationship between information disclosure quality and excess perquisites. The testing samples are adapted from the ShenZhen Stock Exchange Market. It is found that the higher information disclosure quality of the firms is related to the less perquisites consumption by top executives. Moreover, it is also testified that the above relationship is statistically significant in lower business environment index province in China. Finally, internal control index is used as the instrument variable to solve for the possible endogeneity problem. The results further support that the information disclosure quality will reduce the executives' excess perks.
\end{abstract}

Keywords: information disclosure quality, executives' excess perks, top executives' compensation, state owned enterprises

\section{Introduction}

Perquisite consumption (here after named as Perks) commonly exists in business world. Perks can be an alternative of management teams' compensation. Its functions and roles are similar as equity incentive schemes and position promotion; However, due to the implicit features of perks that would reduce the shareholder's wealth, perks consumption also is criticized by the public and the shareholders. Perks are defined as "forms of nonmonetary compensation offered to select employees" (Rajan and Wulf, 2006); According to the SEC's regulation, "a 'perk' is a monetary or non-monetary item of compensation that cannot be properly classified as salary, bonus, or equity-based compensation" (Zhang et al., 2015). In general, perks are a kind of misuse expenses by the employees, especially the managers. In this paper, only top executives' perks are considered.

Perks consumption originated from the agency problems that start from the separation between shareholders and managers. Many researches shed light on the negative consequences of the perks consumption (Berle and Means, 1932; Jensen and Mechling, 1976; Yermack, 2004; Hart, 2001). Similar as the consequences of free cash flow or overinvestment which also relates to agency problems, perks can finally increase the cost of capital and then make the firm value down. However, it is admitted that some researches find that perks have some positive effects on managers. The main contribution of perks is that it can be a part of compensation package for top executives. Perks are an invisible income for the managers compared with the explicit income, such as salary, equity incentive plan, etc. Therefore, perks can be a good incentive method. Moreover, some perks, such as business jets, luxury office rooms, really can increase the working efficiency and then increase the firms value (Rajan and Wulf, 2006; Chen et al, 2010; $\mathrm{Lu}$ et al., 2008). It is found that the sales growth, free cash flow, corporate governance, external regulation, media monitoring, bank ownerships and reputable auditing matter for the perks (Jensen, 1986; Andrews et al, 2009; Luo, et al.2011; Conyon, et al., 2014; Chen et al.,2005). In China, besides the similar results about the reasons and consequences of perks, Chinese researches emphasize more on the specific economic and political backgrounds in China. Chen et al. (2005) and Wang et al. (2014) both find that perks and political promotions in SOEs belong to the implicit compensation, however, they can substitute with each other. They are also the alternative incentive ways to the explicit compensation. These researches investigate that when the top executives have the political promotion expectation, the perks consumption would be reduced. However, it is still not very clear that how to limit the top executives' perks. It is a common idea that better information disclosure quality would lower the cost of debt and cost of equity and further increase the firm value (Brown, 1979; Barry and Brown, 1984, 1985; Easley and O'Hara, 
2004; Lambert et al., 2007; Chen and Liao, 2015; Hui et al., 2015). This research tries to fill into the gap and to investigate whether the explicit information disclosure quality can reduce the top executives' perks consumption. Therefore, this research would add extra contributions to both the perks and information disclosure quality literatures.

This paper is organized as follows: first, the introduction part; Second, the literature review and the hypothesis development; Third, the methodology explanation about the samples collection and main variables definitions in this research; Fourth, the research design and the results regards to the testing hypothesis; Fifth, additional analysis, especially in the endogeneity testing; Finally, the conclusions and further research suggestions.

\section{Literature Review and Hypothesis Development}

\subsection{Prior Research on Perk Consumptions}

In the classical corporate finance theories, it is common belief that the managerial interests are sometimes kept away from the shareholders' interests. When the management teams own less shares and the share structure is highly diversified, the management teams have the incentives to strive for their own benefits rather than the shareholder's wealth (Berle and Means, 1932). Without strict supervisions, the management teams would spend much more non-monetary consumptions simply because these consumptions are charged from the firms rather than their own accounts (Jensen and Mechling, 1976) and these behaviors are not easily observed by other stakeholders. Yermack (2004) investigates the negative consequences of the misuse of the corporate's jets by the executives. This kind of perquisite consumption used wrongly by the executives would make the share price go down and finally decrease the firm's value. In sum, agency theory can explain that the executives excess perks can hurt the firm value (Hart, 2001). However, some scholars believe that perks can also play some positive influences on the firm. In essence, perks can be considered as the implicit monetary compensations. Top executives would be inspired by the perks. The highly motivated management teams can enhance the firm's productivity and then improve the firm value (Rajan and Wulf, 2006; Chen et al, 2010).

Besides the negative and positive consequences arisen from the executive perks, there are some researches on the literature to investigate the possible indicators influencing on the executive perks. When the firm has fewer investment opportunists, the top executives can spend much surplus resources on their own. The executives excess perks are negatively related to the growth opportunities. However, with higher level of free cash flow, the firm does not need raise funds from the outside investors and then less supervision from the outsider stakeholders. Under this situation, the perquisites can be higher with substantial free cash flows. Therefore, the executives excess perks are positively related to the free cash flow (Jensen, 1986). Furthermore, it is found that weakly governed firms would experience a negative market reaction when the news that executives spend large amounts of perquisites are released to the public. Better corporate governance and more external monitoring would limit the executives excess perks consumption (Andrews et al, 2009). Moreover, a research finds that in emerging market, bank ownership can decrease the firm's performance and negatively affect the firm value. The reason is that the bank ownership is significantly associated with the executives' excess perquisites (Luo, et al., 2011). More independent board of directors, more reputable external auditors, higher managerial ownership and more intense market competition matter for the executive excess perk (Conyon, et al., 2014).

In China, there are lots of specific backgrounds which should be considered, such as the high percentage of state-owned enterprises (SOEs), strong government control, etc. Groves et al. (1995) thinks that not only the markets but also the governments and the political interests still influence the managerial decisions in SOEs. In China, managers' supervision and performance evaluation in SOEs are still controlled by the different levels of governments. The new top executives' remuneration regulations specially designed for the central government controlled SOEs requires that the remuneration structure should consist of three parts: basic compensation, performance linked compensation and the incentive scheme (Note 1). The maximum compensation in each part of the compensation package is clearly designed. The compensation control on the SOEs executives would in fact reduce the relative revenue for the top executives in SOEs. This compensation control policy is implicitly originated from the stated owned assets supervision and governmental intervention. The information between the governments (the owners for stated owned assets) and the management teams (the operators for stated owned assets) is highly asymmetric. It is not realist to negotiate with managers one by one and to assess each manager based on their specific performance. Therefore, the standardized compensation packages become the economical choices. Perks as the non-monetary benefits for the managers are the alternatives of compensation. Obviously perks are implicitly originated from the managers' rigid compensation regulation policies that would finally reduce the incentives for the managers (Chen et al., 2005). Contrary to monetary explicit compensation, the perk is a kind of implicit compensation. Due to strict 
compensation control, the perk is preferred to the managers, especially managers in the SOEs. However, more perk consumption would not improve the productivities significantly ( $\mathrm{Lu}$ et al., 2008). The top executives in SOEs play two different roles, one is the manager's role, the other is the government officer's role. Political promotion can also bring benefits for these executives. Political promotion and perks are both implicit compensation. They are the substitute variables for each other. When the executives have the possibilities to be promoted for another higher level position, the perk consumption would be limited and lower. Wang et al. (2014) find that political promotion is negatively related to excess perks.

\subsection{Research on Information Disclosure Quality}

The requirements for disclosing the information of the listed firms are due to information asymmetric. Information disclosure between management teams and other stakeholders play an essential role in reducing the information problem ("Lemon Problem") and the agency problem. Information problem is arisen because managers own more information of the firms than others, such as the outside investors etc. Then it would be possible that the stock prices are overvalued for the 'bad' firms and undervalued for the 'good' firms. The rational investors bid for the stock prices as the average level. So the increased information disclosure can help the markets find the accurate and true stock price levels. Meanwhile, agency problems also matter for the information disclosure. The managers and shareholders do not always have the same interests. The manager's interests are short-term oriented compared with the long-term oriented consideration for the shareholders' interests. If the firms have much free cash flow, the managers can overinvest with the extra free cash flow and also spend many perquisites. All of these finally benefit the managers themselves rather than the shareholders (Healy and Palepu, 2001).

One of the most important economic consequences of information disclosure is that the cost of capital would be influenced and then the firm value be affected simply due to the estimation risk reduction and more precise estimation of the accounting information (Brown, 1979; Barry and Brown,1984, 1985; Easley and O'Hara, 2004). Lambert et al. (2007) find that the accounting information quality would matter for the cost of capital through direct and indirect channels. The direct channel is that the covariance of a firm's cash flows along with other firms' cash flows is influenced by the information quality. Finally, the cost of capital linked with the covariance of cash flows would be influenced; The indirect channel is that the information disclosure quality can affect the management's real decision and then the cash flows. Therefore, the cost of capital is indirectly related to the information disclosure quality through the real decisions on the cash flows (Lambert et al., 2007).

Furthermore, Chen and Liao (2015) indicated that the higher quality of information disclosure would reduce the cost of debt. Hui et al. (2015) shed light on the positive relation between the changes in bonus for top executives and the changes in disclosure quality.

\subsection{Hypothese Development}

Perks expenses have mixed effects on the firms' value. However, any consumption on perquisites more than the normal level must hurt the shareholder's wealth. In 2006, SEC in USA amended the regulation on executive compensation disclosure requirements. The purposes are to increase the information transparence to investors and to avoid any abnormal perquisites consumption. In order to increase the information transparence, the internal and external supervisions on the firms should be used. To build up better corporate governance and internal control system, it is necessary to increase the information transparence. While, there are some external indicators also can reduce the agency problems, such as media reporting, information disclosure quality. Zai et al. (2015) report that media can effectively supervise the listed firms top executives on perquisites consumption. Obviously, increasing the information disclosure quality can also play the similar roles on supervisions of perquisite consumption. Therefore, the assumption is as follows:

Hypothesis 1: The excess perk expenses are negatively associated with the information disclosure quality.

The relationship between information disclosure and the perquisites is influenced by the business environment. The business environments include: the government administrative efficiency, law, tax, financial industry development, labor supply, infrastructure, technology and social factors. For example, how to classify the normal and abnormal perks would be different in different law and regulation world.

Wang, et al. (2013) publish the reports about the composite business environment index (abbreviated as BEI hereafter) in different provinces in China. In the lower BEI provinces, the shareholder protection is always lower compared with the one in the higher BEI provinces. Simply due to the lower base in these lower BEI provinces, increasing the information disclosure quality would be more significant in reducing the excess perks comparing with the results in higher BEI provinces. Then, the second assumption is designed as follows: 
Hypothesis 2: The excess perk expenses are highly related with the information disclosure quality in lower BEI provinces than in higher BEI provinces.

\section{Sample and Measurement about the Main Variable}

\subsection{Sample Selection}

\subsubsection{Data and Sample Selection Procedure}

This paper is to investigate the listed companies in China. Because the information quality index is supplied only in the ShenZhen Stock Exchange Market, the research samples are all selected from the public firms in ShenZhen Stock Exchange Market. ShenZhen Stock Exchange Market consists of three sub-markets: Main Board, SME Board and ChiNext. This research focuses on the main board because the firms listed in it are more representative. The duration is from 2009 to 2012. Besides some data are selected based on screening the financial statements of listed firms, majority financial information originated form CSMAR database. In order to design the balanced panel data sets, this research deleted the following data: (1) financial industries, including the commercial banks, insurance companies, investment banks; (2) B Share firms; (3) ST firms; (4) firms with missing data.

\subsection{Dependent Variable}

\section{Abnormal Perks Expenses}

Perks expenses are not easily observed and measured in an accurate way because these kinds of consumption spent by top executives are always combined with other financial accounts. This paper applies another alternative method to measure perks expenses. This method is adapted by the Luo (2011) and Quan (2010) researches. In their research, the total perquisite expenses consist of normal perks and abnormal perks. Normal perks can explain the corresponding costs for operating the assets, increasing sales, dealing with PPE, holding inventory and supervising the employee, etc. Perks are really needed in a successful business operation. Except for the normal perks expenses, the residual perks would be manager's consumption for their own private benefits. These residual perks are abnormal perks that can represent the excess perks spend by the top executives.

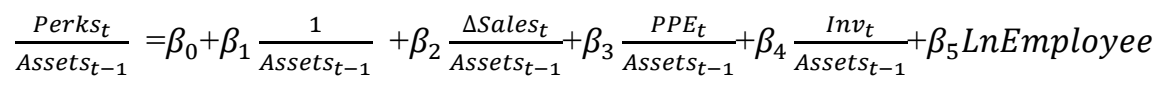

In the model 1, Perks $s_{t}$ is the whole administrative expenses deducted from the top executives' compensation, amortization for the intangible assets and any other expenses that cannot be explained by normal perquisite consumption (Note 2); Asset $_{t-1}$ is the lagged the total assets; $\Delta$ Sales $_{t}$ is the change of sales revenues; $P P E_{t}$ is the amount of property, plant and equipment; Inv $v_{t}$ is the closing balance for the inventories and LnEmployee is the natural logarithm of the number of employees. In order to make all variable in model 1 standardized, all variables are deflated by lagged assets t-1. Firstly, the model 1 is applied for regression by industry and by year. Then the estimated value $(\hat{y})$ based on the model 1 is the normal perks. The abnormal perks $\left(A b P e r k s_{t}\right)$ is the difference between the real perks minus the normal perks $(\hat{\mathrm{y}})$.

\subsection{Testible Variable}

\section{Information Disclosure Quality}

The information disclosure quality is measured by the information disclosure evaluation ranking in the ShenZhen Stock Exchange Market in China. Since 2001, ShenZhen Stock Exchange Market started to announce the listed firm's assessment results of the information disclosure quality. There are 4 dimensions for measuring the information disclosure quality: time, accuracy, completeness and legal. The assessment results are ranked as four levels: excellent, good, pass and fail. In 2011, the four assessment levels are labeled as: A for excellent, B for good, C for pass and D for fail. In this research, the independent variable $D Q I$ (Disclosure Quality Index) is defined as follows: Excellent (A) level is defined as 4; Good (B) level is defined as 3; Pass (C) level is defined as 2 and Failed (D) level is defined as 1.

\subsection{Control Variable}

Control variables consists of several groups: (1) Firm Features Variables; (2) Corporate Governance Variables; (3) Free Cash Flow; (4) External Monitoring Indicator. First, firm Features variables reflects the basic financial conditions. Size which be measured by the total assets with logarithm; CFORatio reflects the firms' operation efficiency. It is the operating cash flows divided by the lagged total assets; Sales Growth measures whether the firms have sufficient revenue or not; Leverage is to show the financial debts levels; State is to classify whether the firms are State Owned Enterprises (SOEs) or not; Age measures the firms' history duration since the firm founded. Second, 
corporate governance variables can make certain whether the firms have good environments to safeguard the interests of shareholders or not. Andrews et al. (2009) shed additional light on the relationship between corporate governance and perquisites. It is found that weak corporate governance is highly correlated with large amounts of perquisites expenses. The control variable to measure the corporate governance levels must be applied. Largest variable measures the percentage of equity ownership for the largest shareholder; LnBoard variable shows the size of BoDs (Board of Directors); Indep variable measures the ratio of independent directors compared with the BoDs' all directors; Comp is defined as the total compensation of the first three top executives. Finally, ICQ, names for the Internal Control Quality, also reflects whether the firms have strong internal control regulations and policies. The ICQ is used for the endogeneity tests. The ICQ is measured by the DIB index which is announced yearly by DIB Enterprise Risk Management Technology Co., Ltd.; BEI is the abbreviation of "Business Environment Index" which measures the enterprises' business environments. This index based on Wang et al. (2013) research reflects the business environments in 8 dimensions.

Table 1. Variable definitions

\begin{tabular}{|c|c|c|}
\hline Variable & Description & Definition \\
\hline AbPerks & Abnormal Perquisites & $\begin{array}{l}\text { Difference between the real perks and estimated normal perks. } \\
\text { Based on Model } 1 \text { (source Luo,2011; Quan,2010) }\end{array}$ \\
\hline DQI & Disclosure Quality Index & $\begin{array}{l}\text { Disclosure Quality Index, ranked from } 1 \text { to } 4 \text { (source ShenZhen } \\
\text { Stock Exchange Market) }\end{array}$ \\
\hline Size & Firm Size & $\begin{array}{l}\text { Total assets in year } t \text {, the natural logarithm in regressions } \\
\text { (source CSMAR) }\end{array}$ \\
\hline CFORatio & Cash Flow Ratio & $\begin{array}{l}\text { Operating cash flow in year } t \text { divided by lagged total assets in } \\
\text { year t-1(source CSMAR) }\end{array}$ \\
\hline SalesGrowth & Sales Growth Rate & $\begin{array}{l}\text { Sales revenue in year } t \text { divided by sales revenue in year } t-1 \text {, then } \\
\text { minus } 1 \text { (source CSMAR) }\end{array}$ \\
\hline Lev & Financial Leverage & $\begin{array}{l}\text { Total liabilities divided by total assets in year } \mathrm{t} \text { (source } \\
\text { CSMAR) }\end{array}$ \\
\hline State & State Owned Enterprises or not & $\begin{array}{l}\text { Dummy variable set equal to } 1 \text { if the firm is the SOE, and } 0 \\
\text { otherwise (source CSMAR) }\end{array}$ \\
\hline LnAge & Firm's Age & $\begin{array}{l}\text { The natural logarithm of the number of years since the firm was } \\
\text { founded (source CSMAR) }\end{array}$ \\
\hline Largest & $\begin{array}{l}\text { Equity ownership ratios for the } \\
\text { Largest Shareholders }\end{array}$ & $\begin{array}{l}\text { Percentage of equity ownership for the largest shareholder } \\
\text { (source CSMAR) }\end{array}$ \\
\hline LnBoard & Board of Directors Size & $\begin{array}{l}\text { The natural logarithm of the number of directors in Board of } \\
\text { Directors in year } t \text { (source CSMAR) }\end{array}$ \\
\hline IndeP & $\begin{array}{l}\text { Percentage of independent } \\
\text { directors in BoDs }\end{array}$ & Percentage of independent directors in BoDs (source CSMAR) \\
\hline Comp & $\begin{array}{l}\text { Compensation for the top } \\
\text { executives }\end{array}$ & $\begin{array}{l}\text { Total compensation for the highest top } 3 \text { executives (source } \\
\text { CSMAR) }\end{array}$ \\
\hline Mhold & $\begin{array}{l}\text { Percentage of shares held by } \\
\text { management team }\end{array}$ & $\begin{array}{l}\text { Percentage of shares held by management team (source } \\
\text { CSMAR) }\end{array}$ \\
\hline BEI & Business Environment Index & $\begin{array}{l}2010 \text { Business Environment Index (Source Wang, x., Yu, J. and } \\
\text { Fan, G., 2013) }\end{array}$ \\
\hline
\end{tabular}

Aggression Model:

AbPerks $_{\mathrm{i}, \mathrm{t}}=\alpha_{0}+\alpha_{1}$ DQI $_{\mathrm{i}, \mathrm{t}}+\alpha_{2}$ Size $_{\mathrm{i}, \mathrm{t}}++\alpha_{3}$ CFORatio $_{\mathrm{i}, \mathrm{t}}+\alpha_{4}$ SalesGrowth $_{\mathrm{i}, \mathrm{t}}+\alpha_{5}$ Lev $_{\mathrm{i}, \mathrm{t}}+\alpha_{6}$ State $_{\mathrm{i}, \mathrm{t}}+\alpha_{7}$ LnAge $_{i \mathrm{t}}+\alpha_{8}$ Largest $_{\mathrm{it}}$ $+\alpha_{9}$ LnBoard $_{\text {it }}+\alpha_{10}$ IndeP $_{\mathrm{i}, \mathrm{t}}+\alpha_{11}$ FthreeExComp $_{\mathrm{i}, \mathrm{t}}+\alpha_{12}$ Mhold $_{\mathrm{it}}+\varepsilon$ 


$$
\begin{aligned}
& \mathrm{AbPerks}_{\mathrm{i}, \mathrm{t}}=\alpha_{0}+\alpha_{1} \mathrm{DQI}_{\mathrm{i}, \mathrm{t}}+\alpha_{2} \text { Size }_{\mathrm{i}, \mathrm{t}}++\alpha_{3} \text { CFORatio }_{\mathrm{i}, \mathrm{t}}+\alpha_{4} \text { SalesGrowth }_{\mathrm{i}, \mathrm{t}}+\alpha_{5} \text { Lev }_{\mathrm{i}, \mathrm{t}}+\alpha_{6} \text { State }_{\mathrm{i}, \mathrm{t}}+\alpha_{7} \text { LnAge }_{\mathrm{it}}+\alpha_{8} \text { Largest }_{\mathrm{it}} \\
& +\alpha_{9} \operatorname{LnBoard}_{i t}+\alpha_{10} \text { IndeP }_{\mathrm{i}, \mathrm{t}}+\alpha_{11} \text { FthreeExComp }_{\mathrm{i}, \mathrm{t}}+\alpha_{12} \text { Mhold }_{\mathrm{it}}+\alpha_{13} \text { BEI_high }_{\mathrm{it}}+\varepsilon \\
& \text { AbPerks }_{i, t}=\alpha_{0}+\alpha_{1} \text { DQI }_{i, t}+\alpha_{2} \text { Size }_{i, t}++\alpha_{3} \text { CFORatio }_{i, t}+\alpha_{4} \text { SalesGrowth }_{i, t}+\alpha_{5} \text { Lev }_{i, t}+\alpha_{6} \text { State }_{i, t}+\alpha_{7} \operatorname{LnAge}_{i t}+\alpha_{8} \text { Largest }_{i t} \\
& +\alpha_{9} \text { LnBoard }_{\text {it }}+\alpha_{10} \text { IndeP }_{\mathrm{i}, \mathrm{t}}+\alpha_{11} \text { FthreeExComp }_{\mathrm{i}, \mathrm{t}}+\alpha_{12} \text { Mhold }_{\mathrm{it}}+\alpha_{13} \text { BEI_low }_{\mathrm{it}}+\varepsilon
\end{aligned}
$$

\section{Research Design and Results}

\subsection{Descriptive Data and Correlation Analysis}

\subsubsection{Descriptive Analysis}

Table 2. Descriptive analysis

\begin{tabular}{llllll}
\hline Variable & Obs & Mean & Std. Dev. & Min & Max \\
\hline AbPerks (millions) & 1516 & 264 & 562 & -144 & 6041 \\
DQI & 1516 & 2.87 & 0.62 & 1 & 4 \\
ICQ & 1516 & 636.86 & 189.56 & 0 & 981.34 \\
Size & 1516 & 21.81 & 1.33 & 18.15 & 25.77 \\
CFORatio & 1516 & -0.47 & 20.76 & -807.99 & 9.50 \\
SalesGrowth & 1516 & 1.37 & 20.80 & -1 & 675.77 \\
Lev & 1516 & 0.59 & 0.72 & 0.01 & 13.71 \\
State & 1516 & 0.68 & 0.47 & 0 & 1 \\
lnAge & 1516 & 2.61 & 0.19 & 1.61 & 3.09 \\
Largest & 1516 & 34.14 & 15.51 & 3.62 & 89.41 \\
lnBoard & 1516 & 2.18 & 0.20 & 1.39 & 2.89 \\
Indep & 1516 & 0.37 & 0.06 & 0.2 & 0.71 \\
Comp (millions) & 1516 & 1.51 & 1.54 & 0 & 17.69 \\
Mhold & 1516 & 0.001 & 0.01 & 0 & 0.29 \\
\hline
\end{tabular}

1,516 observes with 379 listed firms were selected as samples in Table 2. AbPerks and Comp are numerical variables. Their absolute values are large compared with other variables that normally are ratio or logarithm of numbers. Then, AbPerks and Comp are measured in millions for the descriptive analysis, correlation analysis and regression analysis in testing the hypothesis 1 and 2. State is a dummy variable that 1 is for state owned enterprises and 0 for is for non-state owned enterprises. The mean for state is about 0.68 that means the number of state owned enterprises is more than the number of non-state owned enterprises. On average, the mean for $D Q I$ is about 2.87 based on the maximum 4. That shows DQIs for major firms listed in ShenZhen Stock Exchange Markets have good information disclosure quality. The mean for Lev is about 0.59 that reflects that many firms have higher financial leverage. Financial debt could be a challenge for many firms. Largest variable shows that the higher percentage of equity held by major shareholders; while, Indep variable demonstrates that pretty higher ratio of independent directors in board of directors. The mean for Mhold variable is 0.001 that means lower percentage of managers holding the shares. Lower Mhold would reflect that there are smaller incentives for the management teams.

\subsubsection{Correlation Analysis}

Table 3. Correlation for main variables

\begin{tabular}{llll}
\hline & AbPerks(millions) & DQI & ICQ \\
\hline AbPerks(millions) & 1 & & \\
DQI & $0.20 * * *$ & 1 & 1 \\
ICQ & $0.22 * * *$ & $0.37 * * *$ & $0.46^{* * *}$ \\
Size & $0.59^{* * *}$ & $0.35^{* * *}$ & 0.01 \\
CFORatio & 0.01 & -0.01 &
\end{tabular}




\begin{tabular}{llll} 
SalesGrowth & -0.02 & 0.002 & 0.005 \\
Lev & 0.004 & $-0.15^{* * *}$ & $-0.24 * * *$ \\
State & $0.17^{* * *}$ & $0.21^{* * *}$ & $0.10^{* * *}$ \\
lnAge & -0.03 & -0.03 & $-0.10^{* * *}$ \\
Largest & $0.17^{* * *}$ & $0.18^{* * *}$ & $0.14^{* * *}$ \\
lnBoard & $0.16^{* * *}$ & $0.13^{* * *}$ & $0.15^{* * *}$ \\
Indep & 0.04 & -0.01 & 0.04 \\
Comp(millions) & $0.39^{* * *}$ & $0.22^{* * *}$ & $0.27^{* * *}$ \\
Mhold & $0.07^{* * *}$ & -0.02 & 0.03 \\
\hline
\end{tabular}

$*$ significant at $10 \% ; * *$ significant at $5 \% ; * * *$ significant at $1 \%$

Table 4. Correlation matrix

\begin{tabular}{|c|c|c|c|c|c|c|c|c|c|c|c|c|c|c|}
\hline$(\mathrm{obs}=1516)$ & AbPerks & DQI & ICQ & Size & $\begin{array}{l}\text { CFO } \\
\text { Ratio }\end{array}$ & $\begin{array}{r}\text { Sales } \\
\text { Growth }\end{array}$ & Lev & State & $\ln A g e$ & Largest & $\operatorname{lnBoard}$ & Indep & Comp & Mhold \\
\hline AbPerks & 1.00 & & & & & & & & & & & & & \\
\hline DQI & 0.20 & 1.00 & & & & & & & & & & & & \\
\hline ICQ & 0.22 & 0.37 & 1.00 & & & & & & & & & & & \\
\hline Size & 0.59 & 0.35 & 0.46 & 1.00 & & & & & & & & & & \\
\hline CFORatio & 0.01 & -0.01 & 0.01 & -0.01 & 1.00 & & & & & & & & & \\
\hline SalesGrowth & -0.02 & 0.00 & 0.00 & 0.01 & 0.00 & 1.00 & & & & & & & & \\
\hline Lev & 0.00 & -0.15 & -0.24 & -0.08 & 0.00 & 0.01 & 1.00 & & & & & & & \\
\hline State & 0.17 & 0.21 & 0.10 & 0.27 & 0.04 & -0.03 & -0.08 & 1.00 & & & & & & \\
\hline lnAge & -0.03 & -0.03 & -0.10 & -0.07 & -0.02 & 0.04 & 0.08 & -0.11 & 1.00 & & & & & \\
\hline Largest & 0.17 & 0.18 & 0.14 & 0.29 & -0.07 & 0.08 & -0.08 & 0.18 & -0.13 & 1.00 & & & & \\
\hline $\operatorname{lnBoard}$ & 0.16 & 0.13 & 0.15 & 0.26 & 0.00 & 0.00 & 0.04 & 0.17 & -0.03 & 0.00 & 1.00 & & & \\
\hline Indep & 0.04 & -0.01 & 0.04 & 0.05 & 0.02 & -0.02 & 0.01 & -0.05 & 0.01 & 0.03 & -0.33 & 1.00 & & \\
\hline Comp & 0.39 & 0.22 & 0.27 & 0.44 & -0.01 & 0.04 & 0.00 & 0.07 & 0.08 & 0.03 & 0.15 & -0.02 & 1.00 & \\
\hline Mhold & 0.07 & -0.02 & 0.03 & 0.03 & 0.00 & 0.00 & -0.02 & -0.08 & -0.04 & -0.07 & 0.02 & 0.01 & 0.09 & 1.00 \\
\hline
\end{tabular}

Notes: the variables - AbPerks and Comp are measured in millions

The key variables' correlations are demonstrated in Table 3. The Table 4 demonstrates the detail correlation matrix. All the correlations that are statistically significant at $1 \%$ have been marked as 3-star symbol. There are statistical significant for the correlation between AbPerks and DQI. Similarly, AbPerks has strong correlation with Size (0.59) and Comp (0.39). It is also found that $D Q I$ and $I C Q$ have positively correlation (0.37).

\subsection{Multivariate Regression Analysis}

The OLS regression on the table 5 is tested with three different conditions. The $1^{\text {st }}$ column fits for the Model (2), while the $2^{\text {nd }}$ column is the results for the Model (3) and the $3^{\text {rd }}$ column is the results for the Model (4). Based on the Model 2, the regression's results show that AbPerks is negatively related to DQI. This relationship is statistically significant at $10 \%$ confidence level. This testifies that the null hypothesis (1) does exist. In other words, that means that information disclosure quality really can reduce the top executives' abnormal perks.

In order to testify the hypothesis (2), this paper introduces a new variable $B E I$, Business Environments Index, that is commonly applied as the marketization level for different provinces in China. This index is the composite indicator for assessing 8 dimensions in business environments. It reflects the general backgrounds in which the business 
operates. These backgrounds include the law regimes, infrastructures, labor supply, tax, social factors, etc. Because the firms in the regions with lower BEI normally have the following business environment conditions, such as weak corporate governance, stronger government intervention and less developed markets, etc. The fundamental business environment indicators are originally at the lower level. Therefore, the firms in these lower BEI provinces, increase the same level of information disclosure quality would cause much reduction in executives' perks consumption compared with the firms located in higher BEI province. In the $3^{\text {rd }}$ column which is indicated as OLS_With_BEI_Lower, AbPerks is negatively correlated with DQI. This relationship is tested statistically significant at $5 \%$ confidence level. Therefore, the hypothesis 2 does exist.

Table 5. Regression analysis

\begin{tabular}{|c|c|c|c|}
\hline & (1) & (2) & (3) \\
\hline DQI & $\begin{array}{l}-19.82^{*} \\
(11.37)\end{array}$ & $\begin{array}{l}-8.03 \\
(14.17)\end{array}$ & $\begin{array}{l}-41.07 * * \\
(19.52)\end{array}$ \\
\hline Size & $\begin{array}{l}49.65^{* * *} \\
(14.88)\end{array}$ & $\begin{array}{l}68.63 * * * \\
(20.66)\end{array}$ & $\begin{array}{l}52.14 * * \\
(24.47)\end{array}$ \\
\hline CFORatio & $\begin{array}{l}2.74 \mathrm{e}-02 \\
(0.25)\end{array}$ & $\begin{array}{l}2.04 \mathrm{e}-02 \\
(0.25)\end{array}$ & $\begin{array}{l}5.41 \\
(26.43)\end{array}$ \\
\hline SalesGrowth & $\begin{array}{l}-0.27 \\
(0.26)\end{array}$ & $\begin{array}{l}-0.25 \\
(0.26)\end{array}$ & $\begin{array}{l}-0.63 \\
(1.85)\end{array}$ \\
\hline Lev & $\begin{array}{l}15.29 \\
(21.57)\end{array}$ & $\begin{array}{l}12.86 \\
(24.26)\end{array}$ & $\begin{array}{l}21.94 \\
(46.81)\end{array}$ \\
\hline $\ln A g e$ & $\begin{array}{l}258.16^{* * *} \\
(59.95)\end{array}$ & $\begin{array}{l}160.06^{* *} \\
(74.20)\end{array}$ & $\begin{array}{l}388.51^{* * *} \\
(104.73)\end{array}$ \\
\hline $\operatorname{lnBoard}$ & $\begin{array}{l}-20.72 \\
(69.17)\end{array}$ & $\begin{array}{l}-176.18^{* *} \\
(87.09)\end{array}$ & $\begin{array}{l}230.67 * \\
(118.15)\end{array}$ \\
\hline Indep & $\begin{array}{l}4.91 \\
(157.40)\end{array}$ & $\begin{array}{l}-225.84 \\
(200.39)\end{array}$ & $\begin{array}{l}226.38 \\
(256.86)\end{array}$ \\
\hline Comp & $\begin{array}{l}66.39 * * * \\
(6.93)\end{array}$ & $\begin{array}{l}71.77 * * * \\
(7.50)\end{array}$ & $\begin{array}{l}36.82 * * \\
(18.41)\end{array}$ \\
\hline Mhold & $\begin{array}{l}-360.96 \\
(617.17)\end{array}$ & $\begin{array}{l}-1072.64 \\
(1490.03)\end{array}$ & $\begin{array}{l}-67.66 \\
(702.27)\end{array}$ \\
\hline _cons & $\begin{array}{l}-1502.05^{* * *} \\
(338.34)\end{array}$ & $\begin{array}{l}-1297.99^{* * *} \\
(437.91)\end{array}$ & $\begin{array}{l}-2384.32 * * * \\
(575.33)\end{array}$ \\
\hline $\begin{array}{l}N \\
R^{2}\end{array}$ & $\begin{array}{l}1516 \\
0.176\end{array}$ & $\begin{array}{l}1024 \\
0.211\end{array}$ & $\begin{array}{l}492 \\
0.143\end{array}$ \\
\hline
\end{tabular}

Standard errors in parentheses

$* \mathrm{p}<0.1, * * \mathrm{p}<0.05, * * * \mathrm{p}<0.01$ 


\section{Endogeneity Analysis}

Some variables that also influence the dependent AbPerks variable would be missing in the models. So, the endogeneity would be possible in the original regression model. In order to reduce the effects on the endogeneity, the instrument variable (IV) method is used. The instrument variable must be higher correlated with the testable variable $(D Q I)$. Based on the table (3) and (4), internal control quality (ICQ) is a good choice for the instrument variable selection. During the regression process in the endogeneity analysis, AbPerks and Comp are measured in unit digit in order to demonstrate the detail relationships among all the variables. The IV method chooses four different ways, including TSLS, LIML, GMM and IGMM. According to the results on table 6, after reducing the effects of endogeneity, there are even higher negative relationship between $D Q I$ and AbPerks. The relationship is statistically significant at $1 \%$ confidence level. All the endogeneity analysis results are shown on the table 6 .

Therefore, the null hypothesis (1) exists. The information disclosure quality really can reduce the executives' excess perks in China.

\section{Summary}

\subsection{Conclusions}

A perk is a monetary or non-monetary compensation that offered to the specific employees. It's necessary to spend some perks to operate the normal business activities. However, any perk expenditure that exceed the normal level would increase the cost of capital and reduce the firm's value. Therefore, how to limit the consumption of abnormal perks is worthy to investigate. This paper is to find whether there is a negative relationship between the information disclosure quality and top executives' excess perks. After reviewing the literature of previous researches on perquisites and information disclosure quality, the regression analysis is applied. Furthermore, the regression is tested under the BEI indicator which reflects the marketization progress in different provinces in China. Finally, the IV method is also applied in order to reduce the endogeneity effects. All regression models clearly demonstrate that information disclosure quality and executive' excess perks are negatively related in China.

\subsection{Limitations and Further Research Suggestions}

Due to the difficulties of collecting the perquisites consumption data, this paper does not use the direct method that calculate the perks based on the sum of the related accounting expenses, such as travel expenses, conference expenses, transportation expenses, etc. This paper applies the indirect method. In this method, the general accounts balances are used rather than the ledge accounts balances. Therefore, the major weakness in this research is the accuracy problems on the sample data, especially the perks variable data. Further research can try to solve the problems on data collection. Also, this research suggests that the information disclosure quality does matter for the executives' excess expenses. However, current information disclosure quality is only ranked by 4 levels that is very rough for research. In future, more detail disclosure requirements need to be added into the stock markets' supervision regulations.

Table 6. Endogeneity testing

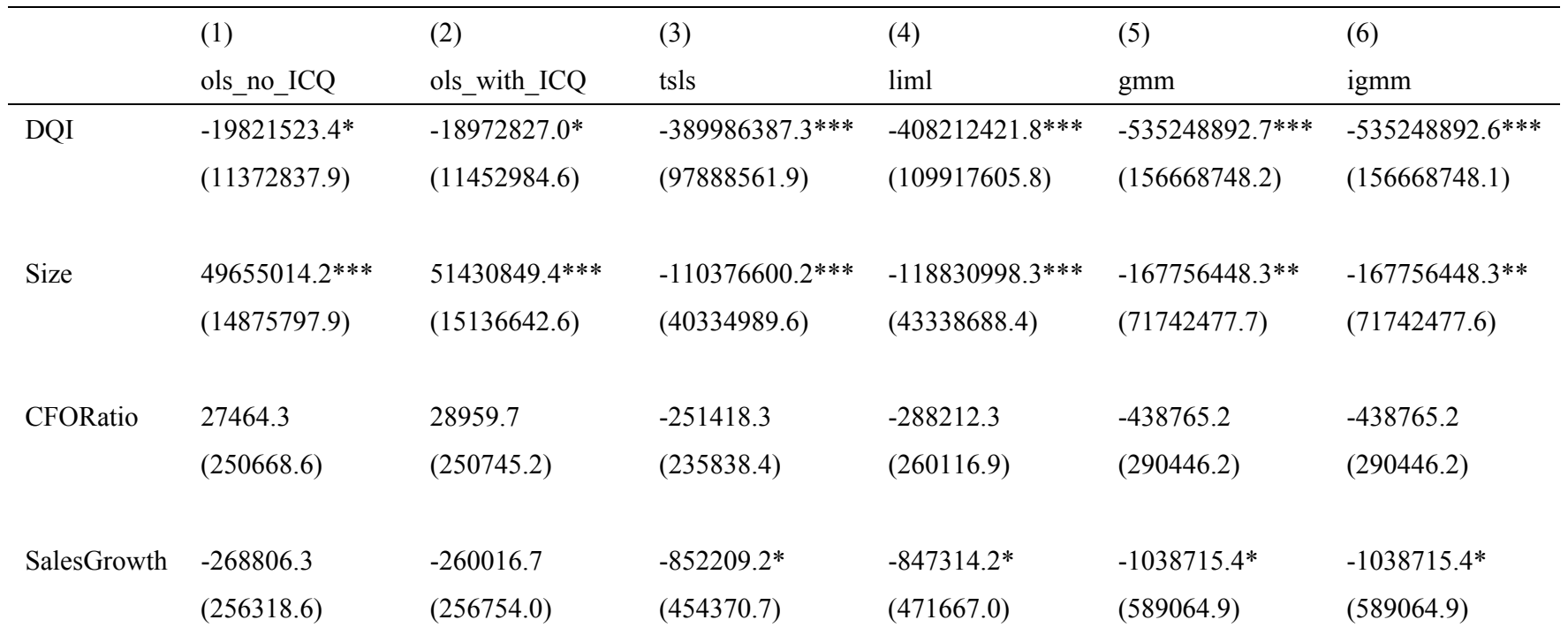




\begin{tabular}{|c|c|c|c|c|c|c|}
\hline Lev & $\begin{array}{l}15287621.2 \\
(21567275.4)\end{array}$ & $\begin{array}{l}14241621.0 \\
(21634861.8)\end{array}$ & $\begin{array}{l}339757225.7^{* *} \\
(164918153.7)\end{array}$ & $\begin{array}{l}356176842.1 * * \\
(179030094.4)\end{array}$ & $\begin{array}{l}445727595.3 * * * \\
(136444586.7)\end{array}$ & $\begin{array}{l}445727595.3 * * * \\
(136444586.7)\end{array}$ \\
\hline lnAge & $\begin{array}{l}258161441.0 * * * \\
(59950635.6)\end{array}$ & $\begin{array}{l}249675746.2 * * * \\
(61417147.5)\end{array}$ & $\begin{array}{l}0 \\
(32129811.2)\end{array}$ & $\begin{array}{l}0 \\
(25674896.4)\end{array}$ & $\begin{array}{l}408424454.3 \\
(254879648.1)\end{array}$ & $\begin{array}{l}408424454.3 \\
(254879648.1)\end{array}$ \\
\hline $\ln$ Board & $\begin{array}{l}-20724271.1 \\
(69173293.1)\end{array}$ & $\begin{array}{l}-18591278.4 \\
(69271799.2)\end{array}$ & $\begin{array}{l}-217900087.1 \\
(154859040.3)\end{array}$ & $\begin{array}{l}-206644941.2 \\
(161300147.2)\end{array}$ & $\begin{array}{l}-382925756.3^{*} \\
(208315074.2)\end{array}$ & $\begin{array}{l}-382925756.6^{*} \\
(208315074.2)\end{array}$ \\
\hline Indep & $\begin{array}{l}4909738.3 \\
(157397077.9)\end{array}$ & $\begin{array}{l}8633108.6 \\
(157546010.4)\end{array}$ & $\begin{array}{l}0 \\
(2166233.1)\end{array}$ & $\begin{array}{l}0 \\
(2541655.8)\end{array}$ & $\begin{array}{l}-977191250.7 \\
(617485050.1)\end{array}$ & $\begin{array}{l}-977191250.7 \\
(617485050.1)\end{array}$ \\
\hline Comp & $\begin{array}{l}66.39 * * * \\
(6.926)\end{array}$ & $\begin{array}{l}66.43 * * * \\
(6.928)\end{array}$ & $\begin{array}{l}6.834 \\
(31.90)\end{array}$ & $\begin{array}{l}0.675 \\
(33.43)\end{array}$ & $\begin{array}{l}-21.00 \\
(45.49)\end{array}$ & $\begin{array}{l}-21.00 \\
(45.49)\end{array}$ \\
\hline Mhold & $\begin{array}{l}-360957988.0 \\
(617169189.0)\end{array}$ & $\begin{array}{l}-337399655.4 \\
(618429457.4)\end{array}$ & $\begin{array}{l}0 \\
(0)\end{array}$ & $\begin{array}{l}0 \\
(0)\end{array}$ & $\begin{array}{l}773646888.3 \\
(4.31289 \mathrm{e}+09)\end{array}$ & $\begin{array}{l}773646891.6 \\
(4.31289 \mathrm{e}+09)\end{array}$ \\
\hline ICQ & & $\begin{array}{l}-24593.2 \\
(38460.0)\end{array}$ & $\begin{array}{l}6370960.5^{* * *} \\
(944278.4)\end{array}$ & $\begin{array}{l}6702621.5^{* * *} \\
(1013366.1)\end{array}$ & $\begin{array}{l}8404907.8^{* * *} \\
(2128359.9)\end{array}$ & $\begin{array}{l}8404907.8 * * * \\
(2128359.9)\end{array}$ \\
\hline _cons & $\begin{array}{l}-1.50205 \mathrm{e}+09 * * * \\
(338340754.6)\end{array}$ & $\begin{array}{l}-1.51089 \mathrm{e}+09 * * * \\
(338711655.2)\end{array}$ & $\begin{array}{l}0 \\
(0)\end{array}$ & $\begin{array}{l}0 \\
(0)\end{array}$ & $\begin{array}{l}0 \\
(0)\end{array}$ & $\begin{array}{l}0 \\
(0)\end{array}$ \\
\hline$N$ & 1516 & 1516 & 1516 & 1516 & 1516 & 1516 \\
\hline$R^{2}$ & 0.176 & 0.177 & . & . & . & . \\
\hline
\end{tabular}

Standard errors in parentheses

$* \mathrm{p}<0.1, * * \mathrm{p}<0.05, * * * \mathrm{p}<0.01$

\section{References}

Andrews, A., Linn, S. C., \& Yi, H. (2009). Corporate Governance and Executive Perquisites: Evidence from the New SEC Disclosure Rules. Working paper. Retrieved from http://ssrn.com

Barry, C., \& Brown, S. (1984). Differential information and the small firm effect. Journal of Financial Economics, (13), 283-294.

Barry, C., \& Brown, S. (1985). Differential information and security market equilibrium. Journal of Financial and Quantitative Analysis, (20), 407-422.

Berle, A., \& Means, G. C. (1932). The Modern Corporation and Private Property. Harvourt. Brace and World Inc., New York, Revised Edition 1967.

Brown, S. (1979). The effect of estimation risk on capita market equilibrium. Journal of Financial and Quantitative analysis, (15), 215-220.

Chen, D. H., Chen, X. Y., \& Wan, H. L. (2005). Regulation and Non-Pecuniary Compensation in Chinese SOEs. Economic Research Journal, (2), 92-101. (in Chinese)

Chen, D. H., Li, O. Z., \& Liang, S. K. (2010). Do Managers Perform for Perks?. Working paper, Nanjing University. 
Chen, T., \& Liao, Y. (2015). The Economic Consequences of Disclosure Quality under SFAS No.131. Accounting Horizons, (29), 1-22. http://dx.doi.org/10.2308/acch-50898

Conyon, M. J., Fang, J. X., \& He, L. R. (2014). Executive Perks and the Horizon effect in China. Working paper. Retrieved from http://ssrn.com

Groves, T., Hong, Y. M., McMillan, J., \& Naughton, B. (1995). China's Evolving Managerial Labor Market. Journal of Political Economics, (103), 873-892.

Hart, O. (2001). Financial Contracting. Journal of Economic Literature, (39), 1079-1100.

Healy, P. M., \& Palepu, K. G. (2001). Information asymmetry, corporate disclosure, and the capital markets: A review of the empirical disclosure literature. Journal of Accounting and Economics, (31), 405-440.

Hui, K. W., \& Matsunaga, S. R. (2015). Are CEOs and CFOs rewarded for disclosure quality? The Accounting Review, (90), 1013-1047. http://dx.doi.org/10.2308/accr-50885

Jensen, M. C. (1986). Agency Costs of Free Cash Flow, Corporate Finance, and Takeovers. American Economic Review, (76), 323-329

Jensen, M. C., \& Meckling, W. H. (1976). Theory of the Firm: Managerial Behaviour, Agency Costs and Ownership Structure. Journal of Financial Economics, 305-360.

Lambert, R. A., Leuz, C., \& Verrecchia, R. E. (2007). accounting information, disclosure, and the cost of capital. Journal of Accounting Research, (45), 385-420. http://dx.doi.org/10.1111/j.1475-679X.2007.00238.x

Lu, R., Wei, M. H., \& Li, W. J. (2008). Managerial Power, Perquisite Consumption and Performance of Property Right: Evidence from Chinese Listed Companies. Nankai Business Review, (5), 85-112. (in Chinese)

Luo, W., Zhang, Y., \& Zhu, N. (2011). Bank Ownership and Executive Perquisites: New Evidence from an Emerging Market. Journal of Corporate Finance, (17), 352-370. http://dx.doi.org/10.1016/j.jcorpfin.2010.09.010

Quan, X., Wu, S., \& Wen, F. (2010). Managerial Power, Private Income and Compensation Rigging. Economic Research Journal, (11), 73-87. (in Chinese)

Rajan, R., \& Wulf, J. (2006). Are Perks Purely Managerial excess? Journal of Financial Economics, 79, 1-33.

Wang, X., Yu, J., \& Fan, G. (2013). Business Environment Index for China's Provinces. China CITIC Press, pp. 14-67.

Wang, Z., Fu, G., Huang, D., \& Wang, J. (2014). The Research on the Relationship between SOEs' CEO "Political Promotion" and "Perquisites Consumption". Management World, (5), 157-171. (in Chinese)

Yermack, D. (2004). Flights of Fancy: Corporate Jets, CEO Perquisites, and Inferior Shareholder Returns. Working Paper. Retrieved from www.ssrn.com

Zai, S., Xu, Y., \& Yang, De. (2015). Can Media Supervise State-owned Enterprise Executives Nor-pecuniary Compensation? Accounting Research, (5), 58-95. (in Chinese)

Zhang, H., Song, Y., \& Ding, Y. (2015). What Drives Managerial Perks? An Empirical Test of Competing Theoretical Perspectives. Journal of Business Ethics, (132), 259-275. http://dx.doi.org/10.1007/s10551-014-2320-7

\section{Notes}

Note 1. The "The Proposal of Remuneration Reform for the Central Supervision Enterprises' Executives" was adopted since Jan. 1st, 2015.

Note 2. In 2006, the new accounting standards adopted in China. In the new accounting standards, 'provisions for bad debts' and 'provisions for impairments of inventory' are not included in the administrative expenses. Therefore, these two accounting items are not deducted from the administrative expenses for calculating the perks expenses. 